\title{
CNTRL/FGFR1 Fusion Protein
}

National Cancer Institute

\section{Source}

National Cancer Institute. CNTRL/FGFR1 Fusion Protein. NCI Thesaurus. Code C99699.

A fusion protein encoded by the CNTRL/FGFR1 fusion gene. This protein is comprised of approximately $75 \%$ of the centriolin protein followed by the tyrosine kinase domains of the basic fibroblast growth factor receptor 1 protein. 